\title{
Opportunity to Learn First Year Mathematics in Teacher Training Colleges in Ghana
}

\author{
Etsey, Y. K. A. (PhD) \\ Department of Educational Foundations, University of Cape Coast, Cape Coast, Ghana. \\ E-mail: kafuietsey@yahoo.com
}

\begin{abstract}
The purpose of the study was to find out students which of the 18 topics in the first year teacher training mathematics syllabus were not taught by the end of the year and which ones were found difficult. Six hundred and ninety-five second year pre-service teachers, made up of 186 females and 506 males, from 18 teacher-training colleges participated in the study. The study was a crosssectional survey and data was collected using a questionnaire. An alpha level of 0.05 was used for all statistical tests. The results showed that two topics, measures of central tendency and conditional probability were not taught. It was found that ten of the eighteen topics were found by the students to be difficult to understand. Further results showed that the Arts students found seven topics more difficult than the Science students and female students also found ten topics more difficult than the males. It is recommended that the teacher training college tutors make efforts to complete the PS1 syllabus. Attempts should be made to integrate the discovery approach into teaching and learning difficult mathematics topics. It is further recommended that more tutorials, extra classes and additional assignments should be given to the Arts and female students.
\end{abstract}

\section{Introduction}

Mathematics is one of the compulsory subjects at the first and second cycles of education in Ghana. At the tertiary level also, a pass in Mathematics at the Senior Secondary School Certificate Examination is a requirement for admission.

In the teacher training colleges in Ghana, Mathematics is studied as a compulsory subject in the first and second years. At the end of each of the first two years, final promotion and Part 1 examinations are taken respectively. The syllabus provides for the teaching of content, dealing with the subject matter of Mathematics and methodology aspects that deal with the pedagogical skills of the subject matter.

The first year Mathematics syllabus for the teacher training college was drawn to equip the teacher trainees with the appropriate knowledge and pedagogical skills to make them competent in the teaching of the subject in the teaching field. The choice of the content in the syllabus is based on needs of the trainees and the children they would be expected to teach in the basic schools after their 
training. The selection was also based on the assumption that the students had had a sound foundation in mathematics in the basic concepts in the first and second cycles of education. This is supported by the fact that the admission requirements demand at least a pass in Mathematics at the senior secondary school certificate examination. By the end of their three year preservice programme, the teachers are expected to have a sound knowledge and foundation in mathematics to teach it effectively.

Steinberg, Haymore and Marks (1985), established a positive relationship between the quality of teachers' knowledge of mathematics and the kind and quality of lessons taught in the classroom. Those with greater conceptual understanding used more conceptual teaching strategies, identified relationships inside and outside the mathematics discipline and engaged students in active problem-solving activities. Leinhardt and Smith (1985) further revealed that teachers' lack of exposure to a rich mathematical knowledge base resulted in their inability to make coherent connections among the different topics taught. Grossman et. al. (1992), and Thompson (1992) also observed that how one teaches a subject is influenced greatly by the many ways one understands it. On the basis of this Asiedu-Addo and Yidana (2000) intimated that teachers in the training colleges in Ghana should possess a sound background in pure mathematics.

To obtain the rich mathematical knowledge and a sound background in mathematics, there should be an opportunity to learn (OTL) which includes the scope of mathematics taught, how the mathematics is taught, and the match between students' entry skills and the new material. Studies (Husen, 1967; 1987; Schmidt, McKnight \& Raizen, 1997) have shown that strong correlations existed between student OTL scores and mean student achievement scores in mathematics. Baratz-Snowden (1993) believed that if students are held accountable for their learning, schools must be held accountable simultaneously for providing students with the opportunity to learn to meet the standards. Winters et. al., (1994) stated further that opportunity to learn (OTL) often serves as part of the evidence for alternative interpretation of student performance. In this vein, Oakes (1989), and Porter (1991) recommended that school administrators, teachers, and policy makers should not judge test results without considering and analyzing students' opportunity to learn (OTL).

Considering the important role of OTL, it is necessary that school and college authorities provide the resources and materials needed to teach mathematics so that teacher trainees gain adequate content knowledge and professional skills before graduating from the teacher training colleges. Sadly, this appears not to be the case in many countries. Tangretti (1993) found that elementary school teachers in Britain were not adequately prepared to meet the expectations in mathematics instruction. It has also been found in Ghana that the knowledge level of the Ghanaian teachers who teach mathematics is low (Asiedu-Addo and Yidana, 2000).

In acquiring content knowledge and skills in mathematics and the subsequent performance, studies have shown that gender differences do exist. Maccoby and Jacklin (1975) in a ground-breaking study in the United States found that males tended to perform better than females. Fennema and Carpenter (1981) reported that the National Assessment of Educational Progress (NAEP) results 
in the United States showed boys outperforming girls. Becker et. al (1990) also reported from a study of 3002 grades 3 through 12 pupils in the United States that boys generally performed better than girls at the upper percentile levels in mathematics problem-solving. Etsey and Snetlzer (1998) conducted a metaanalysis of studies in gender differences in mathematics in the United States and found that boys generally performed better than girls. In the United Kingdom, the Assessment of Performance Unit (APU) reported that at 11 years and beyond, boys perform better than girls. In Ghana, Eshun (1999) found a higher achievement of males than females in the senior secondary school certificate mathematics examination. Wilmot (2001) in a study of primary 3, 4 and 6 pupils observed that statistically significant differences occurred in favour of boys. Criterion-referenced tests conducted by the Ministry of Education for primary 6 pupils in Ghana also showed that the performance of boys was better than girls in mathematics (Quansah, 1996).

In the teacher training colleges in Ghana, very little has been researched and publicly documented on the performance of the students in mathematics though examiners reports have pointed to low performances. The first year promotion examination chief examiners' report of 1999 indicated that a number of topics were found to be posing problems to students due to the lack of understanding of the simple basic principles, theories and concepts underlying those topics. The topics included interpretation of Venn diagrams, number bases, trigonometry and Pythagorean theorem, vectors, and probability. It has not been well researched as to what were the major causes for the students having problems with certain topics. This study attempts to find out students perception of the 18 topics in the PS1 mathematics syllabus. Specifically, an attempt was made to answer the following questions:

(a) Which topics in the PS1 syllabus were not taught by the end of the first year?

(b) Which topics did students find difficult to understand?

(c) What differences exist (if any) among students by the courses they read at senior secondary school in the topics they found difficult?

(d) What gender differences exist, (if any) in the perception of the topics taught?

\section{Method}

\section{Participants}

Six hundred and ninety-five (695) second-year pre-service teachers participated in this study. There were 186 females and 509 males. The pre-service teachers were selected from 18 public teacher-training colleges out of the 38 public teacher-training colleges in the country. The selection of the pre-service teachers was done through a three-stage sampling procedure. The first stage involved randomly selecting seven regions out of the ten regions in Ghana. In the second stage, two public teacher-training colleges in each of the nine selected regions were selected. In regions where there were only two public teacher training colleges, for example, Greater Accra, both of them were taken. However, in the Ashanti and Volta Regions where there were comparatively a large number of teacher training colleges, four colleges were randomly selected 
from both. The third stage involved randomly selecting one second-year (PS2) class out of the number of second-year classes in each college. All the students in the selected classes constituted the sample.

\section{Research Design}

This study is descriptive in nature and designed as a cross-sectional survey that collects information at just one point in time. Surveys serve three main purposes. They make descriptive and explanatory assertions about populations as well as provide a 'search device', when an inquiry is beginning (Babbie, 1990). The main focus in this study was on which topics were not taught, which topics were found difficult, whether any differences exist in students' perception of the topics in terms of gender and courses taken at the senior secondary school levels. To accomplish the objectives of the study, a questionnaire was designed and used to collect data on between December 2002 and March 2003.

\section{Instrument}

A two-section questionnaire was developed for the study. Section A requested background information on gender, programme offered in senior secondary school, grade obtained in senior secondary school certificate examination, and their feelings towards mathematics teaching. Section two lists the topics in the first year mathematics syllabus and participants were instructed to indicate whether each topic was taught and whether the topic was difficult or easy to understand. The instrument as a whole had a Cronbach's alpha of 0.686 as the estimate of its reliability. Section B which contains information pertaining to this study had a Cronbach's alpha of 0.838. Content validity was achieved through reviews and revisions of the draft questionnaire before and after a pilot study. Final year students and a lecturer in educational measurement and statistics from the Department of Educational Foundations, University of Cape Coast designed and validated the instrument.

In the development of the questionnaire, literature on mathematics and the mathematics syllabus for first year students of teacher training colleges in Ghana were first reviewed. A list of items were produced and given to a group of 29 final year (Level 400) students in the Department of Educational Foundations, University of Cape Coast to study and comment on. On the basis of their comments, the statements were reviewed and a likert-scale was produced and developed into a questionnaire. The questionnaire was administered to the first-year (PS1) pre-service teachers at Kommenda teacher training college in Kommenda, Central Region as a pilot study. The responses to the items were analysed and the final instrument made.

\section{Procedure}

Data collection was done in between December 2002 and March 2003. Thirteen teams, each consisting of two or three trained research assistants were sent to the teacher training colleges after permission had been obtained from the principals of the colleges. The questionnaire was completed at one sitting. Instructions were read to the participants and they were given 30 minutes to complete the questionnaire. The participants were assured of anonymity and confidentiality of the responses. For the sake of anonymity, participants were 
told not to write their names on the questionnaire. It was stressed to them that no one known to them would have access to the results of the study and that their names would not be associated with the results. All the 695 participants returned their questionnaires. After the data had been coded and cleaned, all participants' responses were valid for analysis giving a 100\% response rate.

\section{Results}

\section{Topics in the PS1 syllabus that were not taught by the end of the previous academic year}

All eighteen topics in the PS1 syllabus were listed for students to indicate whether they were taught or not. Majority responses of $50 \%$ and above were used as the criteria for acceptance. This implies that where more than half of the class indicated that a topic was not taught, it was accepted as the class decision. The result is presented in Table 1.

Table 1 Status of topics as not taught in PS1 mathematics syllabus

\begin{tabular}{lll}
\hline Topic & $\begin{array}{c}\text { Total number } \\
\text { of responses }\end{array}$ & $\begin{array}{c}\text { \% responses } \\
\text { for topic } \\
\text { not taught }\end{array}$ \\
\hline 1. Sets & 684 & $2.0(14)^{+}$ \\
2. Indices & 689 & $6.5(45)$ \\
3. Number bases & 687 & $7.0(48)$ \\
4. Relations and Functions & 683 & $11.9(81)$ \\
5. Graphs & 688 & $6.3(43)$ \\
6. Algebraic Functions & 682 & $16.0(109)$ \\
7. Solving equations and inequalities & 686 & $4.1(28)$ \\
8. Polygons & 687 & $7.4(51)$ \\
9. Geometric constructions including loci & 680 & $13.1(89)$ \\
10. Circles & 685 & $10.1(69)$ \\
11. Pythagoras Theorem & 686 & $14.6(100)$ \\
12. Movement Geometry & 682 & $36.5(249)$ \\
13. Vectors & 687 & $15.0(103)$ \\
14. Collection and representation of data & 689 & $18.6(128)$ \\
15. Measures of central tendency** & $\mathbf{6 7 9}$ & $\mathbf{5 6 . 8}(\mathbf{3 8 6})$ \\
16. Probability - Experiments and simple events & 688 & $17.3(119)$ \\
17. Probability - Compound events and tree diagrams & 683 & $45.2(309)$ \\
18. Conditional Probability and Pascal triangle & $\mathbf{6 7 7}$ & $\mathbf{6 0 . 7}(\mathbf{4 1 1})$ \\
\hline
\end{tabular}

Note. ${ }^{+}$Numbers in brackets refer to the actual number of responses. ** Topics in bold were not taught.

The results have shown that only two (11\%) of the eighteen topics were generally not taught. About $57 \%$ responded that Measures of central tendency 
were not taught while $60.7 \%$ responded that Conditional Probability and Pascal triangle was not taught.

\section{Topics which students found difficult to understand}

All eighteen topics in the PS1 syllabus were listed for students to indicate which ones they found difficult to understand. The responses ranged from very difficult (1), difficult (2), easy (3) and very easy (4). The percentage responses were those who selected very difficult and difficult from the four options. The lower quartile, (i.e. $25 \%$ of the respondents) and above were used as the criteria for acceptance of difficulty. In the ideal classroom, teachers expect that all $(100 \%)$ of the students understand each topic taught. However, several factors such as previous knowledge, illness, attitude, educational background and teaching learning resources, affect the comprehension ability of each student. It was on this basis that a lower quartile was used as the criterion. This implies that where more than $25 \%$ of the class indicated the topic was difficult to understand, it was accepted as the class decision. The result is presented in Table 2.

Table 2 Difficulty status of PS1 mathematics topics

\begin{tabular}{lcl}
\hline Topic & $\begin{array}{c}\text { Total number of } \\
\text { responses }\end{array}$ & $\begin{array}{c}\text { \% responses on topics } \\
\text { found difficult }\end{array}$ \\
\hline 1. Sets & 659 & $6.8(45)$ \\
2. Indices & 629 & $19.9(125)$ \\
3. Number bases & 618 & $5.9(36)$ \\
4. Relations and Functions** & 591 & $\mathbf{3 3 . 0}(\mathbf{1 9 5 )}$ \\
5. Graphs & 627 & $12.3(77)$ \\
6. Algebraic Functions & 557 & $\mathbf{2 8 . 4}(\mathbf{1 5 8})$ \\
7. Solving equations and inequalities & 635 & $12.6(80)$ \\
8. Polygons & 605 & $16.5(100)$ \\
9. Geometric constructions including loci & 569 & $\mathbf{2 7 . 6}(\mathbf{1 5 7})$ \\
10. Circles & 584 & $\mathbf{4 0 . 8}(\mathbf{1 3 8})$ \\
11. Pythagoras Theorem & 559 & $23.4(131)$ \\
12. Movement Geometry & 396 & $\mathbf{4 3 . 5}(\mathbf{1 7 2})$ \\
13. Vectors & 544 & $\mathbf{3 6 . 8}(\mathbf{2 0 0})$ \\
14. Collection and representation of data & 541 & $14.0(76)$ \\
15. Measures of central tendency & 298 & $\mathbf{3 3 . 3}(\mathbf{9 9 )}$ \\
16. Probability - Experiments and simple events & 539 & $\mathbf{4 2 . 3}(\mathbf{2 2 8})$ \\
17. Probability - Compound events and tree diagrams & 366 & $\mathbf{5 2 . 2}(\mathbf{1 9 1 )}$ \\
18. Conditional Probability and Pascal triangle & 267 & $\mathbf{5 7 . 3}(\mathbf{1 5 3})$ \\
\hline
\end{tabular}

Note. $\quad{ }^{+}$Numbers in brackets refer to the actual number of responses. ** Topics in bold were found difficult to understand.

The results, presented graphically in Figure 1, show that 10 out of the 18 topics were found difficult to understand. The most difficult ones were, Conditional Probability and Pascal triangle (57.3\%), and Probability - Compound events and tree diagrams (52.2\%). The other topics found difficult were, Movement 
Geometry (43.5\%), Probability - Experiments and simple events (42.3\%), Circles $(40.8 \%)$, Vectors $(36.8 \%)$, Measures of central tendency $(33.3 \%)$ and Relations and Functions (33.3\%), Algebraic Functions, (28.4\%), and Geometric constructions $(27.6 \%)$.

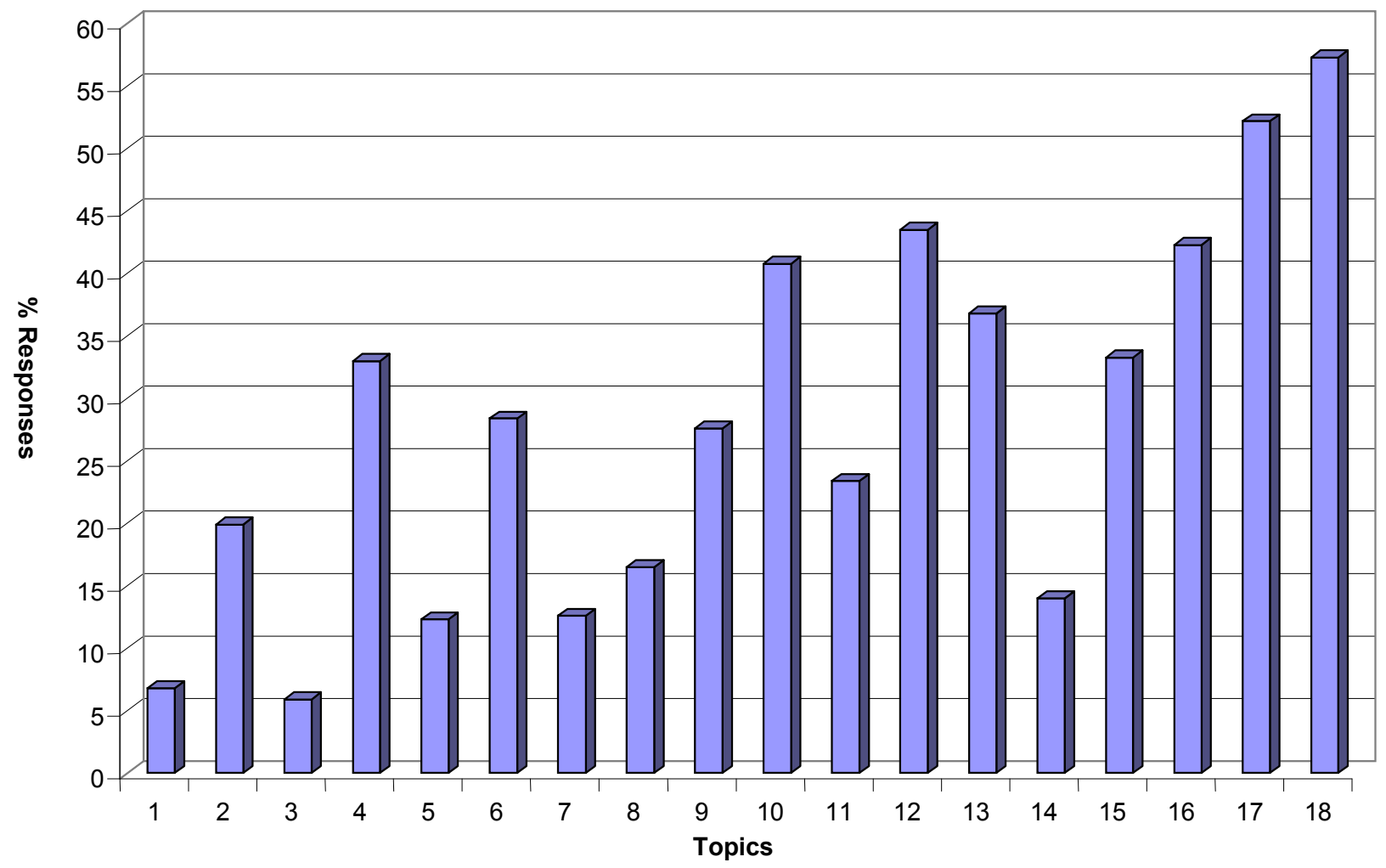

Figure 1 Difficulty level of PS1 Mathematics topics

\section{Differences among students in the topics they found difficult by the programmes they read at SSS}

Participants entered the training colleges after pursuing different programmes at the senior secondary schools. These programmes were General Arts, Science, Home Economics, Visual Arts, Business, Agriculture, and Technical. For the purposes of this study, since some of the programmes did not have adequate number of students, the programmes were grouped into Arts-based (General Arts, Visual Arts) and Science-based (Agriculture, Science, Technical).

Student responses were selected from four options. These were very easy (4 points), easy (3 points), difficult ( 2 points) and very difficult (1 point). Significant differences between the Arts and Science students were tested for all the 10 difficult topics using the independent t-test at the 0.05 level of significance. The results are presented in Table 3. 
Table 3 Independent t-test for course differences in perception of difficulty of PS1 mathematics topics

\begin{tabular}{|c|c|c|c|c|c|c|c|}
\hline Topic & Course & $\mathbf{N}$ & Mean & $\begin{array}{l}\text { Std. } \\
\text { Dev }\end{array}$ & df & $\mathbf{t}$ & p-value \\
\hline \multirow{2}{*}{ 1. Relations and Functions } & Arts & 301 & 2.73 & 0.84 & \multirow{2}{*}{$513^{*}$} & \multirow{2}{*}{-3.59} & \multirow[b]{2}{*}{$0.000^{* *}$} \\
\hline & Science & 235 & 2.99 & 0.80 & & & \\
\hline \multirow{2}{*}{ 2. Algebraic Functions } & Arts & 279 & 2.87 & 0.92 & \multirow{2}{*}{509} & \multirow{2}{*}{-3.28} & \multirow{2}{*}{0.001} \\
\hline & Science & 232 & 3.13 & 0.84 & & & \\
\hline \multirow{2}{*}{$\begin{array}{l}\text { 3. Geometrical constructions } \\
\text { including loci }\end{array}$} & Arts & 285 & 2.94 & 0.88 & \multirow{2}{*}{514} & \multirow{2}{*}{-0.49} & \multirow{2}{*}{0.627} \\
\hline & Science & 231 & 2.98 & 0.89 & & & \\
\hline \multirow{2}{*}{ 4. Circles } & Arts & 290 & 2.56 & 0.94 & \multirow{2}{*}{$513^{*}$} & \multirow{2}{*}{-3.02} & \multirow{2}{*}{0.003} \\
\hline & Science & 237 & 2.80 & 0.90 & & & \\
\hline \multirow{2}{*}{ 5. Movement Geometry } & Arts & 198 & 2.49 & 0.94 & \multirow{2}{*}{$347^{*}$} & \multirow{2}{*}{-3.17} & \multirow{2}{*}{0.002} \\
\hline & Science & 158 & 2.80 & 0.86 & & & \\
\hline \multirow{2}{*}{ 6. Vectors } & Arts & 270 & 2.70 & 0.91 & \multirow{2}{*}{491} & \multirow{2}{*}{-1.72} & \multirow{2}{*}{0.086} \\
\hline & Science & 223 & 2.84 & 0.88 & & & \\
\hline 7. Measures of central tendency & Arts & 148 & 2.74 & 1.03 & $264^{*}$ & -2.40 & \multirow{2}{*}{0.017} \\
\hline \multirow{2}{*}{$\begin{array}{l}\text { 8. Probability - Experiments and } \\
\text { simple events }\end{array}$} & $\begin{array}{l}\text { Science } \\
\text { Arts }\end{array}$ & $\begin{array}{l}120 \\
268\end{array}$ & $\begin{array}{l}3.03 \\
2.58\end{array}$ & $\begin{array}{l}0.89 \\
0.96\end{array}$ & \multirow[b]{2}{*}{$480^{*}$} & \multirow[b]{2}{*}{-2.33} & \\
\hline & Science & 221 & 2.77 & 0.89 & & & 0.020 \\
\hline \multirow{2}{*}{$\begin{array}{l}\text { 9. Probability - Compound events } \\
\text { and tree diagrams }\end{array}$} & Arts & 181 & 2.36 & 0.90 & \multirow{2}{*}{325} & \multirow{2}{*}{-2.00} & 0.047 \\
\hline & Science & 146 & 2.57 & 0.94 & & & $0.04 /$ \\
\hline 10. Conditional Probability and & Arts & 123 & 2.23 & 0.98 & 239 & -1.24 & 0.216 \\
\hline Pascal triangle & Science & 118 & 2.39 & 1.05 & 23 & -1.24 & 0.210 \\
\hline
\end{tabular}

Notes. * Levene's test for equality of variances shows variances are not assumed equal.

**Bold p-values are significant at 0.05 level.

Statistically significant differences were found at the 0.05 level for seven of the ten topics. For all the seven topics, the Arts- based students found them more difficult than the Science-based students. The topics are, Relations and Functions $(\underline{\mathrm{t}}(513)=-3.59, \underline{\mathrm{p}}<0.05)$, Algebraic Functions $((\underline{\mathrm{t}}(509)=-3.28, \underline{\mathrm{p}}<$ 0.05), Circles $(\underline{\mathrm{t}}(513)=-3.02, \underline{\mathrm{p}}<0.05)$, Movement Geometry $(\underline{\mathrm{t}}(347)=-3.17, \underline{\mathrm{p}}<$ $0.05)$, Measures of central tendency $(\underline{t}(264)=-2.40, \underline{p}<0.05)$, Probability Experiments and simple events $(\underline{\mathrm{t}}(480)=-2.33, \underline{\mathrm{p}}<0.05)$ and probability Compound events and tree diagrams $(\underline{t}(325)=-2.00, \underline{p}<0.05)$. No statistically significant differences were found for Geometrical constructions including loci, Vectors, and Conditional Probability and Pascal triangle at the 0.05 level. This latter result implies that both arts and science students found these topics at the same level of difficulty.

\section{Gender differences in the perception of the difficulty of the topics taught}

Student responses were selected from four options. These were very easy (4 points), easy (3 points), difficult ( 2 points) and very difficult (1 point). Significant differences were tested for all eighteen topics in the PS1 syllabus using the independent t-test at the 0.05 level. The result is presented in Table 4 and represented graphically in Figure 2. 
Table 4 Independent t-test for gender differences in perceived difficulty for PS1 mathematics topics

\begin{tabular}{|c|c|c|c|c|c|c|c|}
\hline Topic & Gender & $\mathrm{N}$ & Mean & $\begin{array}{l}\text { Std. } \\
\text { Dev }\end{array}$ & df & $\mathrm{t}$ & $\mathrm{p}$-value \\
\hline 1. Sets & $\begin{array}{l}\text { Female } \\
\text { Male }\end{array}$ & $\begin{array}{l}177 \\
482\end{array}$ & $\begin{array}{l}3.35 \\
3.44\end{array}$ & $\begin{array}{l}0.68 \\
0.63\end{array}$ & 657 & -1.65 & 0.099 \\
\hline 2. Indices & $\begin{array}{l}\text { Female } \\
\text { Male }\end{array}$ & $\begin{array}{l}168 \\
461\end{array}$ & $\begin{array}{l}3.01 \\
3.19\end{array}$ & $\begin{array}{l}0.81 \\
0.80\end{array}$ & 627 & -2.47 & $0.014^{* *}$ \\
\hline 3. Number bases & $\begin{array}{l}\text { Female } \\
\text { Male }\end{array}$ & $\begin{array}{l}170 \\
448\end{array}$ & $\begin{array}{l}3.36 \\
3.52\end{array}$ & $\begin{array}{l}0.67 \\
0.62\end{array}$ & 616 & -2.80 & 0.005 \\
\hline $\begin{array}{l}\text { 2. Relations and } \\
\text { Functions }\end{array}$ & $\begin{array}{l}\text { Female } \\
\text { Male }\end{array}$ & $\begin{array}{l}160 \\
431\end{array}$ & $\begin{array}{l}2.61 \\
2.92\end{array}$ & $\begin{array}{l}0.78 \\
0.84\end{array}$ & 589 & -4.02 & 0.000 \\
\hline 5. Graphs & $\begin{array}{l}\text { Female } \\
\text { Male }\end{array}$ & $\begin{array}{l}171 \\
456 \\
\end{array}$ & $\begin{array}{l}3.09 \\
3.25\end{array}$ & $\begin{array}{l}0.74 \\
0.68\end{array}$ & 625 & -2.66 & 0.008 \\
\hline 6. Algebraic Functions & $\begin{array}{l}\text { Female } \\
\text { Male }\end{array}$ & $\begin{array}{l}149 \\
408\end{array}$ & $\begin{array}{l}2.72 \\
3.05 \\
\end{array}$ & $\begin{array}{l}0.88 \\
0.88\end{array}$ & 555 & -3.89 & 0.000 \\
\hline 7. Solving equations and inequalities & $\begin{array}{l}\text { Female } \\
\text { Male }\end{array}$ & $\begin{array}{l}176 \\
459 \\
\end{array}$ & $\begin{array}{l}3.09 \\
3.42\end{array}$ & $\begin{array}{l}0.85 \\
0.70\end{array}$ & 633 & -5.03 & 0.000 \\
\hline 8. Polygons & $\begin{array}{l}\text { Female } \\
\text { Male }\end{array}$ & $\begin{array}{l}166 \\
439\end{array}$ & $\begin{array}{l}3.04 \\
3.26\end{array}$ & $\begin{array}{l}0.79 \\
0.81\end{array}$ & $305^{*}$ & -3.00 & 0.003 \\
\hline $\begin{array}{l}\text { 9. Geometrical constructions including } \\
\text { loci }\end{array}$ & $\begin{array}{l}\text { Female } \\
\text { Male }\end{array}$ & $\begin{array}{l}149 \\
420\end{array}$ & $\begin{array}{l}2.83 \\
3.01\end{array}$ & $\begin{array}{l}0.83 \\
0.90\end{array}$ & 567 & -2.07 & 0.039 \\
\hline 10. Circles & $\begin{array}{l}\text { Female } \\
\text { Male }\end{array}$ & $\begin{array}{l}155 \\
429\end{array}$ & $\begin{array}{l}2.59 \\
2.69\end{array}$ & $\begin{array}{l}0.80 \\
0.96\end{array}$ & $323 *$ & -1.32 & 0.187 \\
\hline 11. Pythagoras Theorem & $\begin{array}{l}\text { Female } \\
\text { Male }\end{array}$ & $\begin{array}{l}155 \\
404\end{array}$ & $\begin{array}{l}2.79 \\
3.19\end{array}$ & $\begin{array}{l}0.92 \\
0.89\end{array}$ & 557 & -4.60 & 0.000 \\
\hline 12. Movement Geometry & $\begin{array}{l}\text { Female } \\
\text { Male }\end{array}$ & $\begin{array}{l}101 \\
295\end{array}$ & $\begin{array}{l}2.43 \\
2.66\end{array}$ & $\begin{array}{l}0.78 \\
0.95\end{array}$ & $208^{*}$ & -2.51 & 0.013 \\
\hline 13. Vectors & $\begin{array}{l}\text { Female } \\
\text { Male }\end{array}$ & $\begin{array}{l}143 \\
401\end{array}$ & $\begin{array}{l}2.69 \\
2.81\end{array}$ & $\begin{array}{l}0.85 \\
0.91\end{array}$ & 542 & -1.44 & 0.152 \\
\hline $\begin{array}{l}\text { 14. Collection and representation of } \\
\text { data }\end{array}$ & $\begin{array}{l}\text { Female } \\
\text { Male }\end{array}$ & $\begin{array}{l}147 \\
394\end{array}$ & $\begin{array}{l}3.17 \\
3.21\end{array}$ & $\begin{array}{l}0.76 \\
0.72\end{array}$ & 248 & -0.60 & 0.552 \\
\hline 15. Measures of central tendency & $\begin{array}{l}\text { Female } \\
\text { Male }\end{array}$ & $\begin{array}{l}77 \\
221\end{array}$ & $\begin{array}{l}2.81 \\
2.89\end{array}$ & $\begin{array}{l}0.87 \\
0.99\end{array}$ & 296 & -0.64 & 0.520 \\
\hline $\begin{array}{l}\text { 16. Probability - Experiments and } \\
\text { simple events }\end{array}$ & $\begin{array}{l}\text { Female } \\
\text { Male }\end{array}$ & $\begin{array}{l}147 \\
392\end{array}$ & $\begin{array}{l}2.54 \\
2.69\end{array}$ & $\begin{array}{l}0.95 \\
0.93\end{array}$ & 537 & -1.73 & 0.084 \\
\hline $\begin{array}{l}\text { 17. Probability - Compound events and } \\
\text { tree diagrams }\end{array}$ & $\begin{array}{l}\text { Female } \\
\text { Male }\end{array}$ & $\begin{array}{l}94 \\
272 \\
\end{array}$ & $\begin{array}{l}2.44 \\
2.47\end{array}$ & $\begin{array}{l}0.86 \\
0.94\end{array}$ & 364 & -0.35 & 0.730 \\
\hline $\begin{array}{l}\text { 18. Conditional probability and Pascal } \\
\text { triangle }\end{array}$ & $\begin{array}{l}\text { Female } \\
\text { Male }\end{array}$ & $\begin{array}{l}66 \\
201\end{array}$ & $\begin{array}{l}2.32 \\
2.30\end{array}$ & $\begin{array}{l}0.95 \\
1.03\end{array}$ & 265 & 0.137 & 0.891 \\
\hline
\end{tabular}

Notes. * Levene's test for equality of variances shows variances are not assumed equal.

** Bold p-values are significant at 0.05 level.

Statistically significant differences were found at the 0.05 level for 10 of the 18 topics. For all the 10 topics, the female students found them more difficult than the male students. The topics are, topic 2 - Indices $(\underline{\mathrm{t}}(627)=-2.47, \underline{\mathrm{p}}<$ $0.05)$, topic 3 - Number bases $\underline{\mathrm{t}}(616)=-2.80, \underline{\mathrm{p}}<0.05)$, topic 4 - Relations and Functions $(\underline{\mathrm{t}}(589)=-4.02, \underline{\mathrm{p}}<0.05)$, topic 5 - Graphs, $\underline{\mathrm{t}}(625)=-2.66, \underline{\mathrm{p}}<0.05)$, topic 6 - Algebraic Functions $((\underline{\mathrm{t}}(555)=-3.89, \mathrm{p}<0.05)$, topic 7 - Solving equations and inequalities $(\underline{\mathrm{t}}(633)=-5.03, \underline{\mathrm{p}}<0.05)$, topic 8 - Polygons $(\underline{\mathrm{t}}(305)=$ $-3.00, \underline{\mathrm{p}}<0.05)$, topic 9 - Geometrical constructions $(\underline{\mathrm{t}}(567)=-2.07, \underline{\mathrm{p}}<0.05)$, 
topic - 11 Pythagoras theorem $(\underline{\mathrm{t}}(557)=-4.60, \underline{\mathrm{p}}<0.05)$, and topic 12 Movement geometry $(\underline{\mathrm{t}}(208)=-2.51, \underline{\mathrm{p}}<0.05)$. No statistically significant differences were found for the rest of the topics at the 0.05 level. This latter result implies that both female and male students equally found these topics at the same level of difficulty.

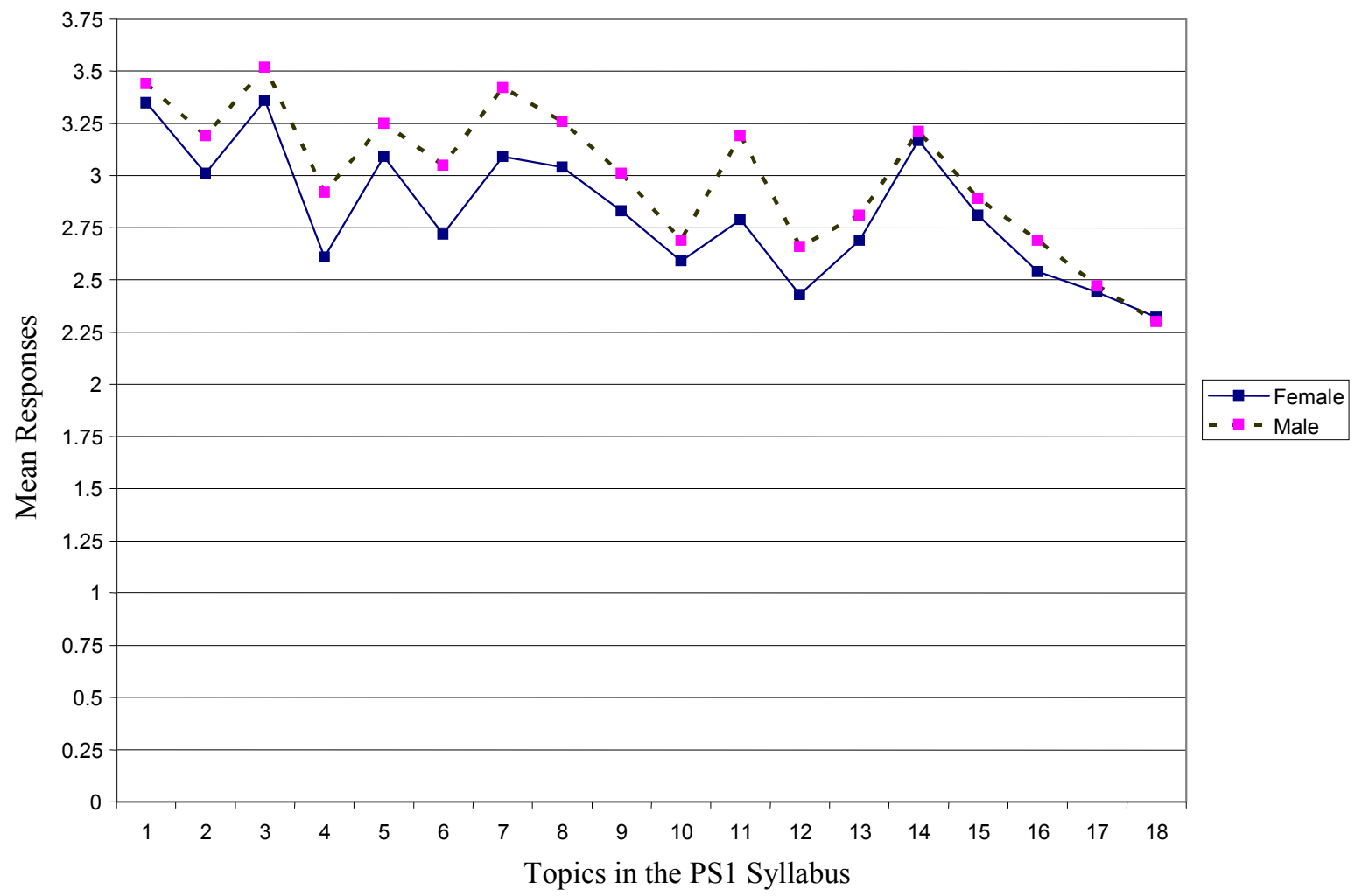

Figure 2 Mean gender responses on perceived difficulty of topics.

\section{Discussion}

The results have shown that two topics, Measures of central tendency and Conditional Probability and Pascal triangle were not taught by the end of the year. Since these topics are not repeated in the second year syllabus, the preservice teachers lost the opportunity to learn these topics. This implies that they do not have the knowledge and skills to be able to teach these topics when they graduate from the teacher training college. In addition, they lost the basic foundation upon which other topics are built. For example, knowledge of measures of central tendency is required for a lesson on measures of variation. The pre-service teachers would therefore find it difficult to understand any lesson on measures of variation.

It is not clear why those two topics were not taught. One reason might be that distractions during the academic year did not allow the academic year to run the full course of the required number of weeks. Secondly, it is possible that the demands of the syllabus are more than the current number of hours per week devoted to the subject. Thirdly and more important might be that the tutors themselves did not have a full grasp of these topics so they were not 
comfortable teaching them. It was therefore not surprising that Probability was one of the topics the chief mathematics examiner in 1999 noted as a problem area. Teacher training college mathematics tutors need to complete the PS1 mathematics syllabus to afford the students the opportunity to learn and acquire the skills needed to work with.

Out of the 18 topics in the PS1 syllabus, pre-service teachers reported that they found 10 of them difficult. The difficult topics were, Conditional Probability and Pascal triangle, Probability - Compound events and tree diagrams, Movement Geometry, Probability - Experiments and simple events, Circles, Vectors, Measures of central tendency, Relations and Functions, Algebraic Functions, and Geometric constructions. The topics the chief mathematics examiners listed such as number bases, Pythagorean theorem, vectors, and probability are found in the topics the students reported as being difficult to understand.

Since students appeared not to be performing well in the topics they found difficult, it implies in one way that the teachers are not teaching such topics too well. Osafo-Affum (2001) observed that many mathematics teachers 'lecture' instead of 'teach'. Teachers give definitions, make no use of concrete materials and practical ways to explain mathematics concepts. Teachers rather give notes on mathematics just as they would do history. Students tend to verbalize their notes without any meaningful understanding. Fawcett (1970), claimed that some of the teachers of mathematics themselves do not clearly understand certain concepts of mathematics. These teachers in effect rather forced the students to learn the concept through rote method. He quoted some teachers as saying, "when students come to my class, I know what they need and I cram it down their throat". It presupposes therefore that many teachers believe that the 'throat' is the 'highway' for learning mathematics. As a result students parrot what they are taught without necessarily understanding the concepts and ideas they symbolize.

It is suggested that the discovery approach to teaching and learning mathematics be one of the ways of teaching the difficult mathematics topics in the teacher training colleges. Discovery learning could either be incidental or guided. Incidental discovery could almost be described as "accidental" in that it results without much planning or synthesizing of what has happened. In contrast, controlled or guided discovery is planned and there are certain understandings that result from the learning experience. Not only is it planned, but also provides an avenue to extend learning by combining the parts into a more complex whole. It does not mean taking the initiative away from the learner, but that the teacher guides the pupil at a level where he/she is capable of achieving a reasonable amount of success. The students' role in discovery requires and encourages the utilization of as many of his/her senses as possible and at times assuming the principal role in searching for a solution, while at other times the search is a co-operative venture with students planning under the teachers guidance. The teacher initially must plan, develop and arrange an environment conducive to learning and discovery but it is the student who must do the actual discovering of relationships and solutions for himself / herself (Wheeler, Ballenger and Hollis, 1965).

Teaching must be hierarchical. The complex tasks must be divided into subtasks to make the performance of the complex task easy. In teaching the 
difficult mathematics topics, the student must be taken upwards through a hierarchy starting from sub-skills which are within the learners' previous competence. At each level the learner puts together two or more of his/her existing skills to achieve the new skill.

It is also important to teach mathematics through various activities linked to other curriculum areas such as Social Studies, Science or Physical education. This because the environment makes an ideal teaching aid much as the nature of activities. This approach would be useful for the teaching of the difficult topics in the PS1 mathematics syllabus. Teachers should link the topics with other subjects such as social studies, integrated science and education. In this way, the students would not treat the topics as on their own but linked to other topics in the teacher training college curriculum and this would provide more opportunities to remember what they were taught in the mathematics class.

Mathematics teachers in the teacher training colleges also need to form an association with the purpose of improving their own knowledge and skills in the teaching of the various topics especially the difficult ones. Another purpose would be to seek ways to improve upon the teaching of mathematics in the teacher training colleges. Workshops and seminars would be helpful in enabling them to acquire more knowledge. The association can also institute the 'Best teacher training mathematics teacher' award as a means of motivating teachers who teach mathematics in the teacher training colleges.

The results of the study have also revealed that differences existed between the Arts-based students and the Science-based students and between the female and the male students in their understanding of topics taught and their perception of the difficulty of the topics. Arts-based students found seven topics more difficult than the Science-based students. The topics were: Relations and Functions, Algebraic Functions, Circles, Movement Geometry, Measures of central tendency, Probability - Experiments and simple events, and Probability - Compound events and tree diagrams. Female students found the following 10 topics more difficult than the male students. The topics were Indices, Number bases, Relations and Functions, Graphs, Algebraic Functions, Solving equations and inequalities, Polygons, Geometrical constructions, Pythagoras theorem, and Movement geometry.

The existence of sub-groups of students who find certain topics more difficult calls for efforts to give more attention to these groups. The Arts-based students as well as the female students should benefit from more tutorials, extra classes and additional assignments in the topics they find more difficult. It is hoped that these efforts would help them to have a greater grasp of the topics. These measures are necessary because of the spiralling effect on the affected groups of students. Since they do not have a good understanding of the topics, they will not be able to teach them effectively when the opportunity to teach arises. This implies that the students who would be taught might also not have a good grasp of the topics. This situation was observed by Grossman et. al. (1992), and Thompson (1992) that how one teaches a subject is influenced greatly by the many ways one understands it. In addition, if these efforts to help the students are not put in place, their performance in the promotion examinations would be affected since the test items cover all the topics in the syllabus. 


\section{Conclusion}

Mathematics is an important subject at the basic education level in Ghana. Teachers who teach at this level need to have not only the methodological skills but also the content knowledge. It is therefore necessary that the pre-service teachers receive adequate training in the content of the PS1 mathematics syllabus. Teacher training college tutors must attempt to teach all the topics and adopt efficient strategies in teaching those topics that have been identified as difficult. In addition, groups such as Arts-based and female students who find certain topics more difficult need addition care so that their failure to understand certain concepts and topics would not affect the children they would teach when they complete their training and begin their teaching careers.

\section{References}

Asiedu-Addo, S. K. \& Yidana, I. (2000). Mathematics teachers' knowledge of the subject content and methodology. Journal of the Mathematics Association of Ghana, 12, 65-71.

Babbie, E. (1990). Survey research methods. Belmont, CA.: Wadsworth Publishing Company.

Baratz-Snowden, J. C. (1993). Opportunity to learn. Implications for professional development. Journal of Negro Education, 62, 311-323

Becker, D., Forsyth, F. \& Robert, A. (1990, April). Gender differences in academic achievement in grades 3 through 12: A longitudinal analysis. Paper presented at the annual meeting of the American Educational Research Association, Boston, USA.

Eshun, B. A. (1999). The pattern of mathematics achievement of secondary school students in Ghana. Journal of Science and Mathematics Education, 21, 22-33.

Etsey, Y. K. and Snetzler, S. (1998) _A meta-Analysis of Gender Differences in Student Attitudes toward Mathematics. ERIC Document Reproduction Service No. ED 435 543. Columbus, OH.

Fawcett, H. P. (1970). The teaching of mathematics from counting to calculus. Columbus $\mathrm{OH}$. Merill.

Fennema, E. \& Carpenter, T. P. (1981). Sex-related differences in mathematics results from national assessment. Mathematics Teacher 74(7), 554-559.

Grossman, P. L., Shulman, L. S. \& Wilson, S. M. (1992), Teachers of substance: Subject matter knowledge teaching. New York, NY: Pergamon Press.

Husen, T. (1967). International study of achievement in mathematics, 2. New York, NY: Wiley and Sons.

Leinhardt, G. \& Smith, D. (1985). Expertise in mathematics instruction, subject matter knowledge. Journal of Educational Psychology, 77(3), 247271. 
Maccoby, E. \& Jacklin, C. (1975). The psychology of sex differences. London, UK: Oxford Universities Press.

Oakes, J. (1989). What educational indicators? The case for assessing the school context. Educational Evaluation and Policy Analysis, 11(2), 181199.

Osafo-Affum, B. (2001). Mathematics crisis in our schools: Causes and remedies. Mathematics Connection, 2, 4-6.

Porter, A. C. (1991). Creating a system of school process indicators. Educational Evaluation and Policy Analysis, 13(1), 13-29.

Quansah, K. B. (2000). 1999 Report on the administration of Primary 6 Criterion-Referenced Tests. Accra: Ministry of Education.

Schmidt, W. H., McKnight, C. C., Raizen, S. A. (1997). A splintered vision: An investigation of US science and mathematics education. Dordrecht, Netherlands: Kluwer Academic Publishers

Shulman, L. (1980). Those who understand knowledge growth in teaching. Journal for Research in Mathematics Education, 27(1)

Steinberg, R., Haymore, J. \& Marks, R. (1985, April). Teachers' knowledge and structuring contents in mathematics. Paper presented at the annual meeting of the American Educational Research Association, Chicago, USA.

Thompson, A. G. (1992) Teachers' beliefs and conceptions: A synthesis of research. New York, NY: Macmillan Pub.

Wilmot, E. M. (2001). Gender differences in mathematics achievement in primary schools in Ghana. Mathematics Connection, 2, 25-29.

Winters, L., Burstein, L., Ang, A., Jo, B., Wang (Moody), J. \& Leonard, J. (1994). What we know about opportunity to learn: Tracking the technical terrain. Paper presented at the 1994 annual CRESST conference, Los Angeles, CA. 